\title{
Using OCLC to Create a Core List of Educational Titles
}

by John D'Amicantonlo and Janet Campbell

\section{INTRODUCTION}

The authors have prepared below a bibliography of core holdings for libraries that include materials for teacher education. All the materials listed are held by over 100 libraries nationwide. Several of the titles are, in fact, held by over 400 libraries. When the authors originally began to consider developing a core collection of educational materials they were motivated by a desire to target books that would benefit students in the Graduate School of Education (GSE). With the onslaught of reduced book budgets and diminishing staff in libraries and universities, it has become even more imperative to identify methods of helping students that are less labor intensive. Librarians at California State University, Long Beach (CSULB) have developed bibliographies of appropriate subject holdings for years, so updating an existing bibliography of educational materials seemed logical.

Many of the students in the Graduate School of Education are already teaching school, either as a substitute, or using an emergency credential until they are fully certified. Many of the students are also interested in obtaining a second credential even though they may currently be working in a public school district as a counselor or other important student personnel position. With this in mind the authors wanted to develop a bibliography that would be truly useful and accurate - one that students would be able to rely on for finding "core" information. The authors used an already existing in-house bibliography that iisted approximately 135 titles of monographs, records, juvenile books and curriculum guides and updated it using specific criteria for the bibliography. The purpose of preparing this selected bibliography, which includes Library of Congress call numbers, was to make it easier for students to locate materials in the CSULB library.

\section{Selection Criteria}

In order to be included in the bibliography each title had to be copyrighted no earlier than 1980 . More importantly, the materials selected must be useful in disciplines that are taught in the Teacher Education and Single Subject Departments. Using the official University Bulletin made identifying appropriate subject areas or disciplines relatively easy. A sample of subjects taught include reading, language arts, social studies and science among many others. Criteria for the bibliography also maintained that the materials on the bibliography must be owned by the University Library. Additional criteria would be included later.

\section{Identifying Subject Headings}

The first step in identifying items for the bibliography was to determine which Library of Congress Subject Headings would be appropriate for our students. Topics of frequent interest to future elementary teachers include areas such as lesson planning, early childhood education and educational games among others. Those preparing for secondary credentials take courses in traditional subjects like English, social studies, science and foreign languages. The authors used these disciplines to determine appropriate subject headings. The books in the bibliography are listed according to locally selected categories, then subdivided by appropriate subject heading. For example, a typical category might be "storytelling." Within each category the list is divided into the appropriate Library of Congress Subject Headings that would be applicable for that category. For instance, the category Reading/Literature is divided into seven LCSH groups: children - books and reading; children's literature; individualized reading instruction; reading (primary); reading (elementary); reading (secondary education); storytelling. Titles meeting the criteria listed above were then selected for each subject heading. This resulted in up to ten titles for each heading. In order to determine if these titles were indeed "core" titles for a teaching education collection, the authors than compared each title to OCLC records. Each title was searched on OCLC to see if other libraries in the U.S. held these in their collections. Of the 139 titles searched only 20 had less than one hundred libraries holding the title. There seemed to be no rhyme or reason as to which titles had such low holdings. The twenty were scattered throughout the selected categories. (We were disappointed that the video version of "Alexander and the Terrible, Horrible, No Good Very Bad Day" was held by fewer than 100 libraries.) The copyright dates varied as did the themes of the books. All the books selected, however, are broad in their scope rather than being too specialized. No more than three titles were selected for each subject heading.

Sinceso many of the 139 titles were held by so many libraries the authors decided to set their final criterion requiring that at least one hundred libraries must hold the title to make the "core" list. The titles which follow "made the list." 
CORE LIST FOR TEACHER EDUCATION

Selected Bibliography

\section{ARTS AND CRAFTS}

Art - Study and Teaching (Primary)

LB1140.5

A7J46

RJ505

A7R8

2984

N350

$\mathrm{H} 47$

1985

LB1591

L36

1983

N350

W26

N350

L465

1980

N350

R47

1988

Juv

Art—Study and Teaching (Elementary)

Herberholz, Donald W.

Lanier, Vincent.

University, 1983.

Wachowiak, Frank. delphia : Harper \& Row, c1985.

Art—Study and Teaching (Secondary)

Linderman, Earl W. c1980. and Ronald N. MacGregor, assistant Association, 1988.

Handicraft—Juvenile Literature

Brown, Osa. House, c1983.
Developing artistic and perceptual awareness: art practice in the elementary classroom.

5th ed. Dubuque, Iowa : W.C. Brown, c1985.

The visual arts and the elementary child.

New York: Teachers College, Columbia

Emphasis art : a qualitative art program for elementary and middleschools. 4thed. Phila-

Teaching secondary school art : discovering art objectives, art skills, art history, art

ideas. 2nd ed. Dubuque, Iowa : W.C. Brown,

Research readings for discipline-based art education: ajourneybeyondcreating/Stephen Mark Dobbs, editor ; Hermine Feinstein editors. Reston, Va. : National Art Education

The MetropolitanMuseum of Art activity book. 1st ed. New York: The Museum : Random
Juv

TT160

G82

1981

LB117

E38

1988

LB1139

L3G46

1989

Greene, Peggy R.

Things to make. New York : Random House, 1981.

\section{EARLY CHILDHOOD EDUCATION}

Early Childhood Education

Egan, Kieran.

Primary understanding : Education in early

childhood. New York; London : Routledge, 1988

LB1140.2

M67

1988

LB1029

O6D38

1983

LB1140.2

L358

1987

LB1523

S66

1985

LB1067

F678

1981

LB1140.2

G73

Gibson, Linda.

Literacy learning in the early years : through children's eyes. New York: Teachers College, Columbia University, c1989.

Morrison, George S.

Early childhood education today. 4th ed.

Columbus : Merrill Pub. Co., c1988.

Education, Primary

Day, Barbara.

Early childhoodeducation : creative learning activities. 2nd ed. New York : Macmillan, c1983.

Lay-Dopyera, Margaret.

Becoming ateacher of young children. 3rd ed. New York : Random House, 1987.

Spodek, Bernard.

Teaching inthe earlyyears. 3rd ed. Englewood Cliffs, N.J. : Prentice-Hall, c1985.

\section{Nursery Schools}

Forte, Imogene.

Kids' stuff : kindergarten and nursery school. Rev. ed. Nashville : Incentive Publications, c1981.

Griffin, Elinor Fitch.

Island of childhood: education in the special world of nurseryschools. New York: Teachers College Prcss, 1982. 


\section{GAMES}

Educational Games

Cratty, Bryant J.

Active learning: games to enhance academic abilities. 2nd ed. Englewood Cliffs, NJ:

Prentice-Hall c1985.

Heitzmann, William Ray.

Educational games and simulations. Rev. ed. Washington, D.C. : National Education Association, c1983.

Play

HQ782

$\mathrm{J} 63$

1987

LB1137

P553

1988

LB1137

S335

1987

Johnson, James E.

Play and early childhood development.

Play as a medium for learning and development : a handbook of theory and prace Heinemann, c1988.

School play: a sourcebook/[edited by]James H.Block, Nancy R. King. New York : Garland
LB1139

L3L3245

1986

LB1139

L3W44

1986

\section{LANGUAGE ARTS}

$$
\text { Children-Language }
$$

Language development in the school years I edited by Kevin Durkin.

Cambridge, Mass. : Brookline Books ; London : Croom Helm, c1986.

Wells, C. Gordon.

The meaning makers : childrenlearning language and using language to learn. 1st ed. Portsmouth, N.H. : Heinemann, c1986.

Creative Writing (Elementary Education)

Mealy, Virginia.

LB1576

M43

1986

From reader to writer: creative writing in the middle grades using picture books. Metuchen,
LB1576

S36

1988 N.J. : Scarecrow Press, 1986.

PE1405

U6C7

1989

LB1631

P66

LB1631

S684

1982
PE1066

T6

1986
B94

1984

LB1576

D467

1984

LB1576

S798

1980

Shelnutt, Eve.

The magic pencil : teaching children creative writing : a workbook for parents and teachers. [Atlanta, Ga.]: Peachtree Publishers, [c1988].

Creative Writing (Secondary Education)

\section{English Language-Composition and Exercises}

$\begin{array}{ll}\text { LB1576 } & \begin{array}{l}\text { Hillerich, Robert L. } \\ \text { Teaching children to write, } K-8: \text { a complete } \\ \text { 1985 }\end{array} \\ & \begin{array}{l}\text { guide to developingwriting skills. Englewood } \\ \text { Cliffs, N.J. : Prentice-Hall, c1985. }\end{array} \\ \text { LB1576 } & \begin{array}{l}\text { Peacock, Colin. } \\ \text { P29 }\end{array} \\ 1986 & \text { Teaching writing. London ; Dover, N.H. : } \\ & \text { Croom Helm, 1986. }\end{array}$

Creative writing in America: theory and pedagogy / edited by Joseph M. Moxley. Urbana, Ill. : National Council of Teachers of English, c1989.

Powell, David.

What can I write about? : 7000 topics for high school students. Urbana, Ill. : National Council of Teachers of English, c1981.

Stanford, Gene.

A guidebook for teaching creative writing. 2nd ed. Boston : Allyn and Bacon, c1982. Croom Helm, 1986.

English Language — Study and Teaching (Elementary)

LB1576 Burrows, Alvina Treut.

To compose : teaching writing in the high school / edited by Thomas Newkirk. Portsmouth, N.H. : Heinemann, c1986. 
English Language - Study and Teaching (Secondary)

$\begin{array}{ll}\text { LB1631 } & \text { Evans, Tricia. } \\ \text { E788 } & \text { Teaching English. London : Croom Helm, } \\ & \text { c1982. }\end{array}$

LB1631

I32

1983

LB1050.5

W488

1982

LB1137

$\mathrm{H78}$

LB1140.5

L3M68

LB1576

A616

1988

LB1576

H334

1986

LB1576

T375

1989

LB1631

I34

1984

PR37

R43

1987
Idea exchange for English teachers. Urbana, Ill, : National Council of Teachers of English, c1983.

Wilkins, Gloria.

Strategies for success : an effective guide for teachers of secondary-level slowlearners. New York : Teachers College Press, 1982.

\section{Language Arts (Primary)}

Humphrey, James Harry.

Help your child learn the $3 R$ 's through active play. Springfield, Ill. : Thomas, c1980.

Moxley, Roy.

Writing and reading in early childhood: a

functional approach. Englewood Cliffs, N.J. :

Educational Technology Publications, 1982.

Language Arts (Elementary)

Anderson, Paul S.

Language skills in elementary education. 4th ed. New York : Macmillan; London : Collier Macmillan, c1988.

Hennings, Dorothy Grant.

Communication in action : teaching the language arts. 3rd ed. Boston, MA : Houghton Mifflin, c1986.

Teachers and research : language learning in the classroom / Gay Su Pinnell, Myna L.

Matlin, editors. Newark, DE : International

Reading Association, c1989.

Language Arts (Secondary)

Ideas plus : a collection of practical teaching ideas. Urbana, Ill. : National Council of

Teachers of English, c1984

Readers, texts, teachers / edited by Bill

Corcoran and Emrys Evans. Upper Montclair, N.J. : Baynton/Cook, c1987.

\section{LESSON PLANNING}

Lesson Planning

$\begin{array}{ll}\text { LB1028.35 } & \text { Dick, Walter. } \\ \text { D53 } & \text { The systematic design of instruction. 2nd ed. } \\ 1985 & \text { Glenview, Ill. : Scott, Foresman, c1985. }\end{array}$

LB1027

H396

1984

Henak, Richard $\mathrm{M}$.

Lesson planning for meaningful variety in teaching. 2nded. Washington, D.C. :National Education Association, c1984.

\section{MATHEMATICS}

Mathematics—Study and Teaching (Primary)

QA135.5 Forseth, Sonia Daleki.

F627

1984

QA135.5

J47

1984

Creative math/art activities for the primary grades. Englewood Cliffs, N.J. : PrenticeHall, 1984.

Jensen, Rosalie.

Teaching mathematics to young children : $a$ basic guide. Englewood Cliffs, N.J. : PrenticeHall, c1984.

Mathematics - Study and Teaching (Elementary)

QA135.5 Elementary mathematical methods / Diane

E35

1989

QA1

N3

1989

F37

1988

QA11

L378

1985

QA12

R43

1988
Thiessen... [et al.]. 3rd ed. New York : Macmillan, c1989.

New directions for elementary school mathematics / Paul R. Trafton, yearbook editor; Albert P. Shulte, general yearbook editor. Reston, Va. : National Council of Teachers of Mathematics, c1989.

Mathematics—Study and Teaching (Secondary)

Farrell, Margaret A.

Secondary mathematics instruction : an integrated approach. Providence, R.I. : Janson Publications, c1988.

Larcombe, Anthony. Mathematical learning difficulties in the secondary school: pupil needs and teacher roles. Milton Keynes [Buckinghamshire]; Philadelphia : Open University Press, 1985.

Readings for enrichment in secondary school mathematics/edited by Max A. Sobel. Reston, VA : National Council of Teachers of Mathematics, c1988. 
Mathematical Recreations

QA241 Brandreth, Gyles Daubeney.

B787

1984

QA95

G325

1988

QA95

M34

1984

Record

9867

M1627

F648

1984

Juv

M1997

G6

1987

MT1

W28

1989

M1993

W776

Walker, Darwin E. Macmillan, c1989.

\section{Singing Games}

Numberplay. New York: Rawson Associates, 1984.

GV443

E5

Gardner, Martin.

Time travel and other mathematical

bewilderments. New York : W.H. Freeman, c1988.

Mandl, Matthew.

Unusual mathematical puzzles, tricks, and oddities. Englewood Cliffs, N.J. : PrenticeHall, c1984.

\section{MUSIC}

\section{Children's Songs}

Carfra, Pat.

Songs for sleepyheads andout-of-beds! [sound recording]. Scarborough, Ontario : Manufactured and distributed by $\mathrm{A} \& \mathrm{M}$ Records of Canada, 1984.

Folk songs North America sings : a source book for all teachers / by Richard Johnston. Toronto : E.C. Kerby, c1984.

Go in and out the window : an illustrated songbook for young people/ music arranged and edited by Dan Fox; commentaryby Claude Marks. New York : Metropolitan Museum of Art ; H. Holt, c1987.

GV443

K47

Music - Instruction and Study

J69

1980

S75

1988

GV443

G14

1989

GV443

G15

1987

1989

\section{PHYSICAL EDUCATION/DANCE}

Dancing—Children's Dances

Elementary curriculum, theory and practice : educational gymnastics, educational games, educational dance / sponsored by the Council on Physical Education for Children, a Council of the National Association forSport and Physical Education. Reston, Va. : American Alliance for Health, Physical Education, Recrea tion, andDance, c1982.

Teaching music : managing the successful music program. New York: Schirmer Books, A Division of Macmillan ; London : Collier

Music experiences for young children. West Nyack, N.Y. : The Center for Applied Re search in Education, 1982.
GV1799

GV1799

LB1062

A47

1989

Joyce, Mary.

First steps in teaching creative dance to children. 2d ed. Palo Alto, Calif. : Mayfield Pub. Co., 1980.

Stinson, Sue.

Dance for young children : finding the magic in movement. Reston, Va. : American Alliance for Health, Physical Education, Recreation, and Dance, c1988.

Physical Education for Children

Gabbard, Carl.

Game, dance, and gymnastic activities for children. Englewood Cliffs, N.J. : PrenticeHall, c1989.

Gabbard, Carl.

Physical education for children : building the foundation. Englewood Cliffs, N.J. : PrenticeHall, c1987.

Kirchner, Glenn.

Physical education for elementary school children. 7thed.Dubuque, Iowa:W.C. Brown Publishers, c1989.

\section{PSYCHOLOGY/CREATIVITY/SELF-ESTEEM}

Creative Thinking (Education)

Amabile, Teresa.

Growing up creative : nurturing a lifetime of creativity. New York : Crown Publishers, 1989.

LB1062 Egan, Kieran.
Imagination and education. New York : Teachers College, Columbia University, c1988. 
Emotions in Children

BF723

E6H37

1989

HQ769

I78

1989

BF723

E6N48

1983

N1009

A1W547

1988

Z1037

A1W645

1989

Juv

PZ5

C57

1981

PN1009

A1P76

1984

Harris, Paul L.

Isaacs, Susan.

Neuman, Susan B. c1983.

Wilson, George. 1988.

Wilson, Mary E.

Children's Literature Macmillan, c1981.

Probst, Robert E.
Children and emotion : the development of psychological understanding. Oxford, UK; New York, NY, USA : Basil Blackwell, 1989.

"I think I can, I know I can!" : using self-talk to help raise confident, secure kids. 1st ed.

New York : St. Martin's Press, 1989.

Exploring feelings : activities for young

children. Atlanta, Ga. : Humanics Limited,

\section{READING/LITERATURE}

Children-Books and Reading

Books for children to read alone : a guide for parents and librarians. New York : Bowker,

Representing children's book characters.

Metuchen, N.J. : Scarecrow Press, 1989.

Classics of children's literature / edited by John W. Griffith, Charles H. Frey. New York:

Adolescent literature : response and analysis. Columbus : C.E. Merrill Pub. Co., c1984.

Individualized Reading Instruction

LB1050.38
C37
1986

LB1050.38

H64

1980
LB1050.53

R87

1981

LB1525.7

F84

LB1525

S34

1986

LB1583.8

B67

1987

LB1573

D44

1989

LB1573

F5

LB1632

C555

1985

LB1632

K3

1984

LB1632

R64

1987
Russell, David Harris.

Reading aids through the grades : a guide to materials and 501 activities for individualizing reading instruction. 4th ed. / by Anne Marie Mueser. New York : Teachers College Press, 1981.

$$
\text { Reading (Primary) }
$$

Fullerton, Claire Jessup.

Teaching reading comprehension : a ten step program. Saratoga, Calif. : R \& E Publishers, c1984.

Schickedanz, Judith A.

More than the ABCs : the early stages of reading and writing. Washington, D.C. : National Association for the Education of Young Children, 1986.

\section{Reading (Elementary)}

Bosma, Bette.

Fairytales, fables, legends, and myths : using folk literature in your classroom. New York : Teachers College Press, c1987.

Devine, Thomas G.

Teaching reading in the elementary school: from theory to practice. Boston: Allyn and Bacon, c1989.

Fields, Marjorie Vannoy.

Let's begin reading right : a developmental approach to beginning literacy. Columbus, Ohio : Merrill Pub. Co., c1987.

Reading (Secondary Education)

Classroom strategies for secondary reading / edited by W. John Harker. 2nd ed. Newark, Del. : International Reading Association, c1985.

Karlin, Robert.

Teaching reading in high school: improving reading in the content areas. 4th ed. New York: Harper \& Row, c1984.

Roe, Betty D.

Secondary school reading instruction : the content areas. 3rd ed. Boston : Houghton Mifflin, c1987.
Gosford, NSW ; New York : Ashton

Scholastic ; Exeter, N.H. : Distributed in the U.S.A. by Heinemann Educational Books, 1980. 
Storytelling

LB1042

L54

1987

\section{Z718.3}

S55

1987

Z718.3

S65

1989
Livo, Norma J.

Storytelling activities. Littleton, Colo. :

Libraries Unlimited, 1987.

Sierra, Judy.

The flannel board storytelling book. [Bronx, NY] : H.W. Wilson Co., 1987.

Smith, Charles A.

From wonder to wisdom : using stories to help children grow. New York : New American Library, c1989.

\section{SCIENCE}

Learning by Discovery

\section{LB1067}

H62

1985

LB1067

K63

1984

LB1140.3

P48

1986

Hodgkin, R. A.

Playing and exploring: education throughthe discovery of order. London; New York :

Methuen, 1985.

Kolb, David A.

Experiential learning: experience as the source of learning and development. Englewood Cliffs, N.J. : Prentice-Hall, c1984.

Peterson, Rosemary.

The Piaget handbook for teachers and parents: children in the age of discovery, preschool- third grade. New York: Teachers College, Columbia University, c1986.

Science-Study and Teaching (Primary)

LB1532

K554

1984

LB1532

P67

1985

LB1585

F69

1986
LB1585

S33

Q181.3
S37

Q181.3

S35

1986

Schmidt, Victor E.

Teaching science with everyday things. 2nd ed. New York : McGraw-Hill, c1982.

Science--Study and Teaching (Secondary)

Science and the early adolescent / compiled by MichaelJ. Padilla. Washington, DC: National Science Teachers Association, c1983.

Science in schools / edited by Joan Brown... [et al.]. Milton Keynes, England; Philadelphia, PA, USA: OpenUniversity Press, 1986.

\section{SOCIAL SCIENCES}

Social Sciences—Study and Teaching (Elementary)

LB1584

E445

1986

LB1584

M43

1988

H62

P685

1984

Elementaryschoolsocial studies : research as a guide to practice/Virginia A. Atwood, editor. Washington, D.C. : National Council for the Social Studies, c1986.

Michaelis, John Udell.

Social studies for children : a guide to basic instruction. 9th ed. Englewood Cliffs, N.J. : Prentice-Hall, c1988.

Principles of social studies : the why, what, and how of social studies instruction / James L. Barth...[et al.]. 2nd ed. Lanham, Md. : University Press of America, c1984.

Social Sciences—Study and Teaching (Secondary)

Knight, Michael E.

The leaves are falling in rainbows : science activities for early childhood. Atlanta, Ga. : Humanics Limited, c1984.

Poppe, Carol A.

Science learning centers for the primary grades.

West Nyack, N.Y. : Center for Applied

Research in Education, c1985.

Science-Study and Teaching (Elementary)

Friedl, Alfred E.

Teaching science to children : an integrated approach. 1st ed. New York : Random House, c1986.
BF575

P9G3

Gabelko, Nina Hersch.

Reducing adolescent prejudices : a handbook. New York : Teachers College Press, Columbia University, 1981.

\section{TEACHING AIDS}

\section{Educational Toys}

LB1029

T6L433

1987

TT174

M38

1983
Lederman, Ellen F.

Educational toys and games : apractical guide to selection and utilization. Springfield, Ill., U.S.A. : Charles C. Thomas, c1987.

McConkey, Roy.

Making toys for hondicapped children : a guide for parents and teachers. Rev. American ed. Englewood Cliffs, N.J. : Prentice-Hall, c1983. 
LB1140.35

T68S56

1986

LB1027

B72

1986

2675

S3T88

1985

LB1043

T487

1988
Sinker, Mary.

Toys for growing : a guide to toys that develop skills. Chicago: Year Book Medical Publishers, c1986. Project Method in Teaching

Brandes, Donna.

A guide to student-centeredlearning. Oxford, OX, England : Blackwell, 1986.

Teaching-Aids and Devices

Thomas, James L.

Nonprint production for students, teachers, and media specialists: a step-by-step guide. 2nd ed. Englewood, Colo. : Libraries Unlimited, 1988.

Turner, Philip M.

Helping teachers teach : a school library media specialist's role. Littleton, Col. : Libraries Unlimited, 1985.

\section{TEACHING IDEAS/ACTIVITIES}

Creative Activities and Seat Work

LB1140.35

Chenfeld, Mimi Brodsky.

Creative activities for young children. New York : Harcourt Brace Jovanovich, c1983.

1983

Vinyard, Gayle.

GV1201

V56

1984

Super treasury of $300+$ activities, games, arts and crafis. Jefferson, N.C. : McFarland, 1984.

LB1537 Wankelman, Willard F.

W3

1985 A handbookof arts andcrafts. 6thed. Dubuque, Iowa : W.C. Brown, c1985.

John D'Amicantonio, Senior Assistant Librarian at California State University Long Beach, received his MSLS from The Catholic University of America in 1988 and his MSEd. from the State University of New York in 1981. He is currently a Social and Behavioural Sciences Librarian.

Janet Campbell, Senior Assistant Librarian at California State University Long Beach has a MSLS from UCLA. She is currently Arts and Humanities Librarians for CSULB, where she also worked as a cataloger for over 20 years. 